Case Study

http://dx.doi.org/10.17784/mtprehabjournal.2014.12.176

\title{
Influence of physical exercise on practice standards morphofunctional, immune function and quality of elderly with aids: case study.
}

\author{
Influência da prática de exercícios físicos sobre os padrões morfofuncionais, função imunológica \\ e qualidade de vida de idosos com aids: estudo de casos.
}

\author{
Ana Paula Serra de Araújo(1), Sônia Maria Marques Gomes Bertoline(2), Joaquim Martins Junior(3), Dennis \\ Armando Bertolini(4), José Alípio Garcia Gouvêa(5).
}

Centro Universitário Cesumar (UniCesumar), Maringá (PR), Brazil.

\begin{abstract}
Introduction: Acquired Immunodeficiency Syndrome (AIDS) is an infectious disease caused by the human immunodeficiency virus (HIV) that causes progressive immunodeficiency virus, rendering the infected individual susceptible to opportunistic infections and diseases. Your clinical treatment is basically medicine and brings with it a number of side effects among which stands out the development of muscle fatigue, lipodystrophy and decreased quality of life. In order to improve the quality of life of people with AIDS, researchers have investigated what kind of benefits to the practice of activity can bring to these individuals. Objective: To evaluate the influence of physical activity on the morphofunctional supervised patterns, immune function and quality of life of elderly patients with AIDS. Method: A descriptive study in which volunteers participated in 4 elderly women with AIDS, who underwent a program of physical activity lasting 16 weeks. Results: The results showed that the proposed program of physical activity was beneficial to functional morphology patterns, immune function and quality of life in older study participants. Conclusion: Sixteen weeks of exercise intervention targeted to elderly patients with AIDS are beneficial, because they promote improvements in the components of morphofunctional standards, with emphasis on flexibility and muscle strength as well as possible changes in markers of immune function and quality domains of life.
\end{abstract}

Keywords: Acquired Immune Deficiency Syndrome, exercise, quality of life.

\section{Resumo}

Introdução: A Síndrome da Imunodeficiência Adquirida (aids) é uma doença infectocontagiosa causada pelo vírus da imunodeficiência humana (HIV) que provoca imunodepressão progressiva, tornando o indivíduo suscetível a infecções e doenças oportunistas. Seu tratamento clínico é basicamente medicamentoso, o qual trás consigo uma série de efeitos colaterais dentre os quais se destacam o desenvolvimento de fadiga muscular, a lipodistrofia e comprometimento da qualidade de vida. Como forma de melhorar a qualidade de vida das pessoas com aids, pesquisadores têm investigado que tipo de benefícios a prática de exercícios físicos pode trazer à esses indivíduos. Objetivo: avaliar a influência da prática de exercícios físicos regulares e supervisionados sobre os padrões morfofuncionais, função imunológica e qualidade de vida de idosos com aids. Método: Estudo descritivo, com a participação de quatro voluntárias idosas portadoras de aids, que foram submetidas a um programa de exercícios físicos com duração de 16 semanas. As variáveis consideradas antes e após o programa de exercícios foram: frequência cardíaca e respiratória, pressão arterial, índice de massa corporal, cirtometria, dobras cutâneas, força muscular dos membros e do tronco, pressão inspiratória e expiratória, flexibilidade, contagem de linfócitos T CD4+ e CD8+ e qualidade de vida. Resultados: Como principais resultados pode-se citar a diminuição da frequência cardíaca, da pressão arterial e da espessura das dobras cutâneas, além do aumento da força muscular e do número de linfócitos T CD4+. Conclusão: Dezesseis semanas de intervenção com exercícios físicos direcionados a pacientes idosos com aids trazem benefícios, pois promovem melhorias nos componentes dos padrões morfofuncionais, com destaque ao grau de flexibilidade e força muscular, bem como possibilitam alterações em marcadores da função imunológica e domínios da qualidade de vida.

Palavras-Chave: Síndrome da Imunodeficiência Adquirida, exercício físico, qualidade de vida.

\section{Received: 28 January 2014. Accepted: 28 April 2014. Published: 6 May 2014.}

1. Master student in Promoção da Saúde, Centro Universitário Cesumar (UniCesumar), Maringá (PR), Brazil.

2. Professor, Centro Universitário Cesumar (UniCesumar) e Universidade Estadual de Maringá (UEM), Maringá (PR), Brazil.

3. Professor, Centro Universitário Cesumar (UniCesumar), Maringá (PR), Brazil.

4. Professor, Universidade Estadual de Maringá (UEM), Maringá (PR), Brazil.

5. Master student in Promoção da Saúde, Centro Universitário de Maringá (UniCesumar), Maringá (PR), Brazil. 


\section{INTRODUCTION}

The Acquired Immunodeficiency Syndrome (AIDS) was identified in 1981 in the United States of America (USA) ${ }^{(1-3)}$ and, since then, is characterized as an infectious disease caused by the human immunodeficiency virus (HIV). ${ }^{(4)}$

Clinically, the disease manifests itself through a sequence of stages: the acute phase of infection, or other clinical asymptomatic latency then the initial or early symptomatic phase and, finally, AIDS is the final stage of virus infection HIV. At this stage, the progressive immunosuppression characterized by the decline in the concentration of CD4 + lymphocytes in the blood stream throughout the course of HIV infection occurs. Still associated with a progressive and involuntary loss of body weight, which, left untreated, leads to death the infected individual. ${ }^{(5,6)}$

Estimates of the incidence of HIV infection indicate that in 201239,185 new cases were reported, and the incidence rate of AIDS in Brazil was 20.2 cases per 100 thousand inhabitants. ${ }^{(7)}$

Surveys also show that in June 2013 there were 718,000 reported cases of AIDS in the country, among which $64.9 \%$ of infected individuals were men and $35.1 \%$ women. ${ }^{(7)}$ However, the number of older HIV-infected individuals and AIDS has increased significantly since the beginning of the last decade, there statistics that show that currently in Brazil, 6.2 men and 3.5 women per 100 thousand individuals aged $\geq 60$ years are infected with HIV. ${ }^{(8)}$

In seeking to combat immunosuppression generated by viral infection and improve the quality of survival of infected individuals, have been researched different therapies. Among these, there is drug treatment, which is done through the combination of different antiretroviral drugs (ARV) aimed at controlling the clinical manifestations and the opportunistic diseases that arise with the evolution infection. ${ }^{(9)}$

Although drug treatment for cases of HIV/AIDS has doubled the life expectancy of infected individuals, ${ }^{(10)}$ it is known that antiretroviral therapy (ART) in long term, causes significant side effects, especially in kidney, liver and in the immune system of the patient. ${ }^{(9)}$

The main side effects of ART involve increased vulnerability to mitochondrial toxicity, hypersensitivity and lipodystrophy, which makes it more prone seropositive to metabolic syndrome and risk factors for cardiovascular disease. ${ }^{(11-14)}$

These side effects have made them different strategies to minimize them are investigated. Mostly involve the use of alternative medicines and the practice of regular and supervised exercise. ${ }^{(13)}$

The recommendation of exercise for people with AIDS has been the subject of numerous scientific investigations that seek to verify what benefits these exercis- es can provide patients with AIDS. ${ }^{(14-17)}$ However, among elderly patients with AIDS research is scarce. ${ }^{(17)}$

In this context, the present study aimed to verify the influence of regular and supervised practice on the functional morphology patterns, immune function and quality of life of elderly women with AIDS exercise.

\section{METHOD}

The present study was characterized as a search quantitative, prospective, case report type. Was performed after obtaining written consent of the directors responsible for the Centro de Capacitação de Profissionais da Saúde (CECAPS), Serviço de Atendimento Especializado (SAE) in DST/AIDS from Maringá, after obtaining approval from the Ethics Committee research Involving Human Subjects of the Centro Universitário de Cesumar (UniCesumar) under opinion n. o 197.392/2012.

To achieve the proposed objectives, the study was planned in six phases. The first was held on the premises of SAE and aimed to identify and trace the profile of the elderly aids from the city of Maringa, Parana, which could participate in the study. In this phase we investigated the records of all registered elderly in the period between January and June 2012, the medical records of patients who died, those aged $\leq 60$ years without medical records information and seniors transferred to another SAE being excluded.

According to the analysis of the records was made a list of seniors who previously met the inclusion criteria of the study (age $\leq 60$ years diagnosed with AIDS, with adherence to ART, and counting of CD4 + T lymphocytes $\geq 150$ cells $/ \mathrm{mm}^{3}$ ).

The second stage was to recruit the pre-selected subjects via telephone or in person contact in the same queries in the SAE during the period December 2012 to March 2013. During recruitment, the elderly were invited to attend a pre-scheduled meeting for the month of March 2013 in the physiotherapy clinic UniCesumar. At meeting were explained the objectives of the study, its purpose and methods, as well as the informed consent term for signature of the elderly who agreed to participate voluntarily in the study.

Also in March 2013, has begun the third phase of the study, in which assessments of morphological and functional patterns (heart rate, respiratory rate, height, weight, body mass index - BMI, circumference and thickness of subcutaneous skinfolds) were performed, assessment of functional patterns (manovacuometry test and six minutes walk test - 6MWT), flexibility test and tests of muscle strength for upper and lower limbs), assessment of immune function ( $T$ lymphocytes CD4 + and CD8 +) and assessment of quality of life of older people (WHOQOL-HIV-bref questionnaire).

During evaluation of morphological and functional patterns, proceeded to the weighing and measuring the 
height of the elderly using a mechanical professional anthropometric scale with stadiometer (up to $150 \mathrm{~kg}$ of Balmak brand). Subsequently, we calculated BMI using the formula $\mathrm{BMI}=$ weight $(\mathrm{kg}) /$ height $^{2}\left(\mathrm{~m}^{2}\right)$.

Cirtometry was performed using a rubberized tape measure with scale of 0 to 150 centimeters $(\mathrm{cm})$. The thickness of subcutaneous folds was performed by using the caliper - caliper Scientific Premier Cescorf.

Functional assessment was performed by running the test manual pressure, maximum repetitions per minute (abdominal, arm flexion and squat), flexibility (by using the Wells box equipment) and manual pressure (using a dynamometer analog hand with precision of $1 \mathrm{~kg} / \mathrm{d}$ ).

The assessment of cardiac function was performed through the measurement of systolic and diastolic blood pressure levels, through the use of a sphygmomanometer and stethoscope BD brand; measurement of heart rate $(H R)$, respiratory rate (RR) by counting and measuring the saturation ( $\mathrm{SpO} 2)$ through the use of finger oximeter unit brand SB100 Rossmax, and manuvacuometry performed by using the manometer Manovac brand and six-minute walk test (6MWT) test.

To perform the 6MWT, initially calculating the predicted distance for females was done using the formulas suggested by Enright and Sherrill(18) whose values achieved during tests subsequently underwent calculation of mean and standard deviation.

The evaluation of immune function due to the exercise was done by quantifying of CD4 + and CD8 + lymphocytes and the relation CD $4+/ C D 8+$. To obtain the values of absolute and relative lymphocyte count was held to collect data on the results of periodic examinations of SAE, realized by Laboratório de Ensino e Pesquisa em Análises Clínicas (LEPAC) of Universidade Estadual de Maringá (UEM), as routine ever performed with the assisted patients on Maringá SAE- Paraná, contained in the medical records. For immunological evaluation were considered the results of laboratory tests before and after completion of the exercise program.

The evaluation of quality of life was performed by applying the quality of life questionnaire drafted in 2002 by the World Health Organization (WHO), called Quality of Life Assesssment HIV (WHOQOL-HIV-Bref), abbreviated version of WHO, in Portuguese. ${ }^{(19)}$

WHOQOL-HIV-bref consists of 31 questions and 6 domain scores denoting the perceived quality of life of individuals in the following areas: physical, psychological, level of independence, social relationships, environment and spirituality.

However, the calculation of the WHOQOL-HIV-Bref follows a different logic of the other WHOQOL. The questions are scored individually on a scale of 5 points Likert model, in which 1 indicates high, positive perceptions, it means better quality of life, and 5 indicates low and negative perceptions, which means, worse quality of life. It isn't done calculating the scores of the domains and facets of the WHOQOL-HIV-Bref and do not realize the arithmetic mean of the components of the domain. No conversion of the scores of the domains and facets to a scale from 0 to 100 and also not provided the criterion for elimination of participants who failed to respond or responded incorrectly more than $20 \%$ of the questions of the instrument. (20) However, for the calculation of descriptive statistics scores and WHOQOL-HIV-Bref, aiming to abolish the above limitations, we used Microsoft Excel software - software broad accessibility, available at the following electronic site: http://www .brunopedroso.com.br / WHOQOL-hiv.htm W. instruments. ${ }^{(21)}$

The exercise program (fourth phase of the study) was carried out between the months of May and August 2013 in a gym physical education twice a week, always on Tuesdays and Thursdays, the hours of 9: 00 - 10:00 h, lasting 16 consecutive weeks.

The program comprised 10 minute warm-up (stretching and calistemics exercises), 15 minutes of aerobic exercise at an intensity that did not exceed the HR 150 beats per minute (bpm), in order to avoid possible immunosuppression induced by high intensity; 30 minutes of strength training in which the resistance exercise involving large and small muscle groups (pectoralis major, latissimus dorsi, quadriceps, biceps, triceps brachii, calf muscles and abdomen) were performed. Each exercise was performed for three sets of 15 repetitions with a rest period between each series of one minute. Thereafter, for 5 minutes was done slowdown (stretching and breathing relaxation techniques).

All proposed physical exercises were performed in a circuit and every three weeks were reviewed and amended. At the end of 16 weeks of implementing the exercise program, the participants were re-evaluated and the results submitted to descriptive statistics.

\section{RESULTS}

The results obtained during the epidemiological survey showed that between January and June 2012 there were 99 HIV-infected elderly monitoring and clinical treatment in SAE of Maringá - Paraná. Of these, 59 elderly $(59.59 \%)$, of which $24(40.57 \%)$ were female and $35(9.32 \%)$ were male, resided in the city of Maringá - Paraná.

It was possible to make contact with 43 elderly $(72.88 \%)$, which were invited to participate in the study. Of these, $1(2.32 \%)$ claimed to have no interest in participating, $5(11.72 \%)$ were excluded because they were users of wheelchairs and/or experiencing difficulty in ambulation, and $1(2.32 \%)$ by find-was hospitalized.

Of the 43 seniors invited to participate in the study, $7(16.27 \%)$ attended the pre-scheduled in Physiotherapy Clinic UniCesumar for the inauguration of the study 
and signing the informed consent.

Three volunteers $(42.85 \%)$ were excluded due to inability to participate assiduously in physical exercise program. Anyway, 4 elderly effectively participated in the study, which represented $4.04 \%$ of the target population.

Table 1 shows the distribution of older study participants according to socio-demographic and health characteristics.

Table 2 shows the results of the initial assessment and end of the corresponding morphological and functional patterns to anthropometric and cardiorespiratory elderly study participants. It is observed that the proposed exercise program promoted reduction of $H R$, blood pressure (BP), respiratory rate, BMI, circumference and skinfold thickness evaluated.

Table 3 presents the results of the initial functional assessment and the corresponding end of the manovacuometry, flexibility test, maximum repetitions per minute and manual pressure study. The results revealed an increase in respiratory muscle strength of the lower limbs and abdomen as well as increased flexibility.
Table 1. Distribution of voluntary study participants with AIDS, according to socio-demographic characteristics and health conditions. Maringá - Paraná, 2013.

\begin{tabular}{|c|c|c|}
\hline Characteristics & Variables & Frequency \\
\hline Gender & Female & $4(100 \%)$ \\
\hline Age & $\begin{array}{l}61 \\
63 \\
64 \\
65\end{array}$ & $\begin{array}{l}1(25 \%) \\
1(25 \%) \\
1(25 \%) \\
1(25 \%)\end{array}$ \\
\hline Race / skin color & $\begin{array}{l}\text { Black } \\
\text { White }\end{array}$ & $\begin{array}{l}2(50 \%) \\
2(50 \%)\end{array}$ \\
\hline Marital status & $\begin{array}{l}\text { Widow } \\
\text { Single }\end{array}$ & $\begin{array}{l}3(75 \%) \\
1(25 \%)\end{array}$ \\
\hline Education & 1st degree & $4(100 \%)$ \\
\hline Salary income & 1 minimum wage & $4(100 \%)$ \\
\hline Mode of Infection & $\begin{array}{l}\text { heterosexual relation- } \\
\text { ship }\end{array}$ & $4(100 \%)$ \\
\hline Time of HIV infection & $\begin{array}{l}14 \text { years } \\
17 \text { years } \\
9 \text { years }\end{array}$ & $\begin{array}{l}1(25 \%) \\
2(50 \%) \\
1(25 \%)\end{array}$ \\
\hline AIDS phase & $\begin{array}{l}\text { Asymptomatic } \\
\text { Symptomatic }\end{array}$ & $\begin{array}{c}4(100 \%) \\
0(00 \%)\end{array}$ \\
\hline Healthy condition & $\begin{array}{l}\text { Regular } \\
\text { Good } \\
\text { Very good }\end{array}$ & $\begin{array}{l}1(25 \%) \\
2(50 \%) \\
1(25 \%)\end{array}$ \\
\hline
\end{tabular}

Table 2. Morphofunctional patterns of voluntary study participants related to cardiorespiratory assessment and anthropometric profile. Maringá - Paraná, 2013.

\begin{tabular}{|c|c|c|c|}
\hline Variable & & Initial assessment & Final assessment \\
\hline Heart Rate (bpm) & & $77.5 \pm 8.54$ & $73.5 \pm 18.83$ \\
\hline Blood pressure & Diastolic (mmHg) & $78.5 \pm 5.00$ & $78.75 \pm 1.25$ \\
\hline Respiratory Rate (rpm) & & $18.75 \pm 5.25$ & $17.5 \pm 3.41$ \\
\hline \multicolumn{2}{|l|}{ Body Mass Index $\left(\mathrm{Kg} / \mathrm{m}^{2}\right)$} & $23.67 \pm 2.72$ & $24.19 \pm 2.96$ \\
\hline \multirow{3}{*}{ Cirtometry } & Hips (cm) & $363 \pm 9.91$ & $353.9 \pm 9.23$ \\
\hline & Waist (cm) & $336.5 \pm 8.94$ & $315 \pm 9.97$ \\
\hline & Brachial triceps $(\mathrm{cm})$ & $98.9 \pm 3.94$ & $93.2 \pm 4.03$ \\
\hline \multirow{3}{*}{ Thickness of Skin Folds } & Subscapular (mm) & $19.1 \pm 2.23$ & $15.6 \pm 2.31$ \\
\hline & Abdominal (mm) & $27.1 \pm 1.14$ & $21.8 \pm 0.97$ \\
\hline & Triceps (mm) & $14.5 \pm 1.07$ & $8.84 \pm 0.99$ \\
\hline
\end{tabular}

kilograms per square meter, $\mathrm{cm}$ - centimeters; $\mathrm{mm}$ - millimeters.

Table 3. Functional assessment of voluntary study participants. Maringá - Paraná. 2013.

\begin{tabular}{|c|c|c|c|}
\hline Variables & Tests & Initial assessment & Final assessment \\
\hline \multirow{2}{*}{ Manovacuometry } & $\operatorname{MIP}\left(\mathrm{cmH}_{2} \mathrm{O}\right)$ & $91.5 \pm 26.75$ & $103.25 \pm 16.87$ \\
\hline & $\operatorname{MEP}\left(\mathrm{cmH}_{2} \mathrm{O}\right)$ & $80 \pm 14.96$ & $98 \pm 9.09$ \\
\hline Flexibility & Wells box $(\mathrm{cm})$ & $23.7 \pm 7.42$ & $26.55 \pm 7.22$ \\
\hline \multirow{2}{*}{ Maximum Repetition } & Abdominal (MR) & $31.75 \pm 11.14$ & $44.5 \pm 8.42$ \\
\hline & Squat (MR) & $19 \pm 21$ & $30.25 \pm 5.56$ \\
\hline \multirow{2}{*}{ Manual pressure } & Right antimere (kgf) & $21.675 \pm 1.93$ & $23.15 \pm 1.64$ \\
\hline & Left antimere (kgf) & $20.575 \pm 2.32$ & $21.925 \pm 1.36$ \\
\hline
\end{tabular}

* Values expressed as mean and standard deviation. Subtitle: MIP - maximum inspiratory pressure; MEP: maximum expiratory pressure; $\mathrm{cmH}_{2} \mathrm{O}$ - centimeters of water; $\mathrm{cm}$ - centimeters; MR - maximum resiatance; kgf - Kilogram-force. 
Table 4 presents the comparative results of the final and initial assessment in relation to functional capacity and cardiopulmonary elderly according to the 6MWT. The data show that the proposed exercise program promoted increased functional capacity of participants. This can be evidenced by the increase of $10.75 \%$ in the amount of distance traveled regardless of elderly already present exercise capacity above the predicted value before the start of the physical activity program.

The influence of physical exercise on immune function analyzed by determining the relative and absolute count of CD4 + and CD8 + and CD4 + / CD8 + is presented in Table 5 . Note that the proposed exercise program promoted an increase in CD4 + T lymphocytes.

Finally, Table 6 presents the results of analysis of quality of life assessed before and after the implementation of the physical activity program proposed by using the WHOQOL-HIV-Bref. It is observed that the proposed program of physical exercises in alterations in quality of life of older participants. We notice that the best areas in the first stage of the program were the social relations and the environment, and at the end of the program became the spirituality / religion / personal beliefs and overall quality of life and general health perception domains.

\section{DISCUSSION}

The benefits of regular physical exercise for the human body are well known and among them stands the improvement of cardiorespiratory function, strength, endurance, muscle flexibility, quality of life and reducing the level of stress and anxiety. ${ }^{(22)}$ In individuals with AIDS, the benefits are no different. However, it is known that patients with AIDS suffer constantly with nutritional, organic and metabolic changes associated or not with the use of ART. ${ }^{(23-24)}$

Although research suggest the benefits of regular physical exercise for patients with AIDS, and knowing that many HIV-positive individuals have an interest in performing physical exercises to improve their quality of survival,(25-26) the difficulty in getting AIDS patients, es- pecially older age, becomes a limiting factor for studies with significant samples to investigate the real benefits of physical exercise for seropositive patients. The main difficulties in conducting surveys of this nature due to the low adherence to exercise programs proposed, opportunistic infections and sociodiscriminatives issues, since HIV/AIDS do not want to be identified as seropositive afraid prejudices of others participants. ${ }^{(25)}$ All these difficulties were observed during the planning and completion of this study, which could explain the small sample selected.

Considering the cases studied, the results showed that the proposed program of exercise was beneficial to functional morphology patterns, immune function and quality of life in the majority of older study participants. The program promoted a reduction in HR, RR, SBP, cirtometry hip, waist and triceps as well as the thickness of the subscapular, triceps and abdominal subcutaneous folds, increasing only BMI.

According Matsudo, Matsudo-Neto and Barros(27) and Freitas Oliveira and Santos(28), the practice of regu-

Table 4. Distances traveled by the elderly during the 6 min walk test (6MW - Predicted) at initial and final assessment. Maringá - Paraná. 2013.

\begin{tabular}{lcc}
\hline & Initial Assessment & Final Assessment \\
Distance $(\mathrm{m})$ & $\mathbf{6 2 3 . 0 6 \pm 8 1 . 8 7}$ & $\mathbf{6 9 0} \pm \mathbf{6 0 . 0 0}$ \\
\hline $\begin{array}{l}\text { Predited value } \\
(\mathbf{m})\end{array}$ & $521.72 \pm 150.19$ \\
\hline * Values expressed as mean and standard deviation. Subtitle: $\mathrm{m}$ - meter.
\end{tabular}

Table 5. Total T lymphocyte count CD $4+$ and $C D 8+$ and the relation CD4 +/CD8 + before and after participation in an exercise program. Maringá - Paraná. 2013.

\begin{tabular}{lll}
\hline $\begin{array}{l}\text { Immunological } \\
\text { parameters }\end{array}$ & $\begin{array}{l}\text { Initial Assessment } \\
\text { Cells } / \mathbf{m m}^{3}\end{array}$ & $\begin{array}{l}\text { Final Assessment } \\
\text { Cells } / \mathbf{m m}^{3}\end{array}$ \\
\hline T CD4+ & $631.75 \pm 357.16$ & $736.75 \pm 244.97$ \\
$\begin{array}{l}\text { T CD8+ } \\
\begin{array}{l}\text { Relation CD4+/ } \\
\text { CD8+ }\end{array}\end{array}$ & $0.685 \pm 0.45$ & $1.081 \pm 896.35$ \\
\hline * Values expressed as mean and standard deviation. Subtitle: Cells $/ \mathrm{mm}^{3}$
\end{tabular}

- cells per millimeters cubed.

Table 6. Distribution of scores of WHOQOL-HIV-Bref the elderly study participants expressed by its mean and standard deviation at the beginning and end of the exercise program. Maringá - Paraná. 2013.

\begin{tabular}{|c|c|c|}
\hline Domain & Initial Assessment & Final Assessment \\
\hline I - Physical & $13.75 \pm 2.29$ & $12.25 \pm 2.06$ \\
\hline II - Psychological & $11.60 \pm 2.65$ & $11.8 \pm 2.87$ \\
\hline III - Level of independence & $14.75 \pm 2.62$ & $14.25 \pm 2.87$ \\
\hline IV - Social relations & $11.50 \pm 3.31$ & $12.75 \pm 0.50$ \\
\hline VI - Spirituality/religion/personal beliefs & $15.75 \pm 2.06$ & $13.25 \pm 2.06$ \\
\hline VII - Overall quality of life and general health perception & $13.50 \pm 3.41$ & $11 \pm 4.76$ \\
\hline Total Score & $12.93 \pm 1.86$ & $12.71 \pm 2.03$ \\
\hline
\end{tabular}

* Values expressed as mean and standard deviation. 
lar exercise provides direct positive effects on maintaining and/or increasing muscle mass free of fat. In addition to preventing the loss of muscle mass free of fat, regular exercise enhances energy metabolism of the individual, increasing the cross section of the muscle fibers, thus your muscle volume, capillarization and your caloric burn. Thus, the increase in fat free muscle mass, decreasing fat by burning calories and optimization of body metabolism as a result of regular physical exercises, such as those proposed in this study can potentially explain the increase in BMI of elderly and a reduction in body measurements. Moreover, this increase in BMI shows that the proposed program of exercise was effective in combating the major side effects of ART and AIDS, which is the progressive reduction of body weight.

Another fact to be noted is that in the case of AIDS patients on ART, these are often exposed to develop lipodystrophy, which is characterized by excessive concentration of fat in the abdomen, chest and neck, and loss of fat in the face, arms and legs, which can also come to be characterized by loss of fat from the skin more apparent in the arms, legs, buttocks and face, resulting in weakness of the face, buttocks and apparent atrophy of the veins in the legs and arms. ${ }^{(29)}$

It was noted that the proposed program of physical activity promoted reduction measures, especially in the abdominal region, assisting in combating and reducing the lipodystrophy presented by older research participants. Moreover, this result reinforces the findings of Santos et al.(30), who assessed the effects of an exercise program for people with AIDS, were also on the average decrease in body fat levels by assessing the thickness of folds cutaneous and cirtometry with greater reduction measures in the region of trunk (waist, abdomen and hips).

Regarding the influence of exercise on blood pressure levels, studies show that physical exercise promotes regulate a number of physiological responses resulting from autonomic and hemodynamic adaptations that can help in promoting the reduction of blood pressure levels ${ }^{(31)}$ and that physical exercise is one of the main non-pharmacological therapeutic measures used to hypertensive patients, aiming to reduce blood pressure levels and cardiovascular risk factors. ${ }^{(32)}$ Accordingly, the exercise program proposed in this study reinforces these findings to, although moderately, promoting a reduction in $S B P, H R$ and $R R$.

Bearing in mind that among individuals with AIDS and the elderly is common to reduced muscle strength occur $^{(33)}$ the physical exercises such as those proposed by this study proved to be safe and likely to materialize for maintenance and gain muscle strength and flexibility of older AIDS patients as well as for optimizing their functional performance. It was found that among older study participants the proposed exercise program pro- moted an improved morphology and bring benefits to physical and functional capability of the same, characterized by increased muscle strength of upper and lower limbs as well as the abdominal muscles.

The improvement in respiratory muscle strength can also be seen by the increase in MIP and MEP. However, we must emphasize that there are few studies that assess the conditions of the cardiorespiratory system especially elderly individuals with AIDS and that the evaluation of these variables, not yet widespread in the literature, can contribute to an analysis of the side effects of ART on the system cardiorespiratory and how the syndrome affects this system, since studies show that there is an increased cardiovascular risk due to metabolic complications and that individuals with AIDS tend to have significant cardiorespiratory changes, not only associated with aging as well as the use of ART. ${ }^{(34)}$

Regarding the results obtained during the execution of the 6MWT, it appears that even elderly women with AIDS showed good cardiorespiratory and functional capacity to perform physical exercise, since the same, while performing the initial evaluation, the results achieved above the recommended range for the predicted pattern. The result of the final evaluation of the 6MWT showed that the proposed program promoted an enhancement of cardiorespiratory and functional capacity of these elderly. Thereby increasing scientific evidence that a program of physical exercise in which you use aerobic and strength training can positively affect the cardiorespiratory and neuromuscular parameters, making it possible to promote the development of physical fitness and cardiorespiratory endurance and improve functional capacity ${ }^{(35)}$ These results reaffirm Roberts and Avila(36), that physical resistance exercises, such as those used in the present study, promote cardiovascular fitness of seropositive.

In a recent literature review, the authors conclude that prescribing exercise aimed at patients with HIV/ AIDS, with or without the use of antiretroviral drugs is beneficial because of possible improvements in physical fitness components, such as maximum oxygen consumption and degrees of flexibility and muscle strength, and enable changes in several markers of immune function in patients with HIV/AIDS. ${ }^{(37)}$

In this study, the proposed exercise program enabled the improvement of immune function, since there was an increase in the number of T lymphocytes CD4 + without reduction in the $\mathrm{CD} 4+/ \mathrm{CD} 8+$ ratio in the whole sample. These results are similar to those found by Souza et al. (38), who studied in the elderly of both genders, people with HIV, the effect of strength training performed twice a week for one year on the count of $\mathrm{T}$ lymphocytes CD4+ and CD8+. These authors observed a significant increase in the count of T lymphocytes CD4 + and $\mathrm{CD} 4+/ \mathrm{CD} 8$ + ratio, not being verified no signifi- 
cant increase in the count of T lymphocytes CD8 + . It is noteworthy that the CD4 + T lymphocytes are the main cells of the immune response in assisting the activation of other components of the immune response and are the main cells infected by HIV.

Full activation of CD8 + T lymphocytes virgins and their differentiation into cytotoxic $\mathrm{T}$ lymphocytes and memory cells may require the involvement of CD4 $+\mathrm{T}$ helper lymphocytes. The fact that no increase in CD8+ T lymphocytes in the present study have been found can be explained by functional impairment of CD4 + helper, observed in individuals infected with HIV, which infects and eliminates only the CD4 + T lymphocytes. Although this study observed an increase from 0.68 to 0.73 in the $\mathrm{CD} 4+/ \mathrm{CD} 8+$, this number was not significant. In healthy individuals, the CD4 +/CD8 + ratio is approximately two CD4+ $\mathrm{T}$ lymphocytes for CD8+ T lymphocytes. ${ }^{(39)}$

Several factors modulate the magnitude of the effects of exercise on the immune system, such as type, duration and intensity of exercise and fitness, the age of the subject and nutritional status. Physical exercise can be considered a potent immunosuppressant when performed at a high intensity, resulting in immunosuppression and increased incidence of infections. However, if the exercise is carried out with moderate intensity and sufficient recovery, their action could result in improved immune response. Several mechanisms may be involved in modulating the effect of exercise on the immune system, including changes induced on stress hormones, changes on the cellular glutamine metabolism and body temperature changes, increased blood flow, lymphocyte apoptosis and dehydration. ${ }^{(40)}$

The results achieved by this study showed that it would be possible to administer a physical fitness program efficiently and safely in elderly patients with AIDS, getting most of these individuals between the desirable benefits of improved immune function and functional morphology patterns, which, according to Pinheiro and Gadelha ${ }^{(33)}$, would improve the quality of survival in these individuals.

Regarding quality of life, this has been a constant concern of WHO, especially when thinking about chronic diseases such as AIDS. According Kluthcovsky and Kluthcovsky ${ }^{(41)}$, quality of life can be identified as a more general concept, not being directly associated with the disease or health interventions. However, studies as- sessing the quality of life of people living with AIDS, regardless of age, use various instruments, most of whom have used the term quality of life related to health (HRQOL), assessing the impact of health social activities and mobility, focusing on the presence or absence of signs and symptoms and effects of new drugs and health interventions. Not contemplating, therefore, aspects such as the level of satisfaction with one's own life and at the same time, making it difficult to compare results between studies.

Using the WHOQOL-HIV-Bref, it was revealed at the end of the exercise program, no change in the overall score. However, we noticed an improvement in the field relationships and social environment. According to Santos, France Junior and Lopes ${ }^{(42)}$, AIDS patients have better quality of life - physical and psychological - that other patients and worse scores in social relationships domain. Being that this area could reflect the processes of stigma and discrimination associated with difficulties in diagnostic disclosure in social settings (work, family and friends) and a quiet sex life. These findings, and the results of this research suggest that AIDS can negatively affect issues in social relationships domain (personal relationships, social support, sexual activity), thus emphasizing the importance of associating the practice physical exercises to pharmacological therapeutic interventions.

The present study has some limitations, such as the fact that the sample was reduced by the limitations inherent in the physical exercise by patients with AIDS. More studies are needed with a larger number of older people with AIDS and a program of physical exercise lasting at least six months with a frequency of at least three times a week.

\section{CONCLUSION}

This study demonstrated that 16 weeks of exercise intervention targeted to elderly patients with AIDS provide them with important benefits, because they promote improvements in the components of morphofunctional standards, mainly in the degree of flexibility and muscle strength, and enable changes in markers of immune function and domains of quality of life. These results may represent the first step towards scientific evidence that supervised exercise are also beneficial for patients aged over 60 years, without, however, causing damage and injury on disease progression.

\section{REFERENCES}

1. Nobre AQ, Cavalcanti ISC, Bernardes KO. A fisioterapia no contexto do HIV/aids. Fisioter Mov. 2008; 21(4):11-18.

2. Ceccon RF, Marisco NS. A AIDS no município de Cruz Alta, RS: o perfil da epidemia e suas características. Lecturas Educación Física y Deportes. 2011; 16(163):1-5. Disponível em:< http://www.efdeportes.com/efd156/aaids-perfil-da-epidemia.htm.> Acesso em: 05 out. 2012. 
3. Silva RAR, Duarte FHS, Nelson ARC, Holanda JR. A epidemia de AIDS no Brasil: Análise do perfil Atual. Rev Enfern UFPE on line. 2013; 7(10):6039-6046. Disponível em:

4. <http://www.revista.ufpe.br/revistaenfermagem/index.php/revista/article/viewFile/4882/pdf_3678>

5. Santos FF. Immunological and virological characteristics and performance in the variables flexibility and abdominal resistence strength of HIV/aids adolescents under highly active antirretroviral therapy. Rev Bras Med Esporte. 2013; 19(1): 40-43.

6. Deresz LF, Lazzarotto AR, Manfroi WC, Gaya A, Sprinz E, Oliveira AR, et al. O estresse oxidativo e o exercício físico em indivíduos HIV positivo. Rev Bras Med Esporte. 13(4):275-279, 2007.

7. Brasil. Ministério da Saúde. Secretaria de Vigilância em Saúde. Departamento de DST, Aids e Hepatites Virais. Recomendações para a prática de atividades físicas para pessoas vivendo com HIV e aids. Brasília: Ministério da Saúde; 2012.

8. Brasil. Ministério da Saúde. Secretaria de Vigilância em Saúde - Departamento de DST, Aids e Hepatites Virais. Boletim Epidemiológico aids/DST: até semana epidemiológica 26a - dezembro de 2013. Brasil: Ministério da Saúde; 2013.

9. Faria JB, Seidl EMF. Religiosidade, enfrentamento e bem-estar subjetivo em pessoas vivendo com HIV/aids. Psicologia em Estudo. 2006; 11(1):155-164.

10. Juchem GMV, Lazzarotto AR. Treinamento físico na síndrome lipodistrófica: revisão sistemática. Rev Bras Med Esporte. $2010 ; 16(4): 310-313$.

11. Raso V, Casseb JSR, Duarte AJS, Greve JMA. Uma breve revisão sobre exercício físico e HIV/AIDS. Rev Bras Ci e Mov. 2007; 15(4):99-110.

12. Hawkins T. Understanding and managing the adverse effects of antiretroviral therapy. Antiviral Research. 2010; 85(1):201-209.

13. Brasil. Ministério da Saúde. Secretaria de Vigilância em Saúde. Departamento de DST, Aids e Hepatites Virais. Recomendações para a prática de atividades físicas para pessoas vivendo com HIV e aids. Brasília: Ministério da Saúde; 2012.

14. Gomes RD, Borges JP, Lima DB, Farinatti PTV. Efeito do exercício físico na percepção de satisfação de vida e função imunológica em pacientes infectados pelo HIV: Ensaio clínico não randomizado. Rev Bras Fisioter. 2010; 14(5):390-395.

15. Roubenoff R, Wilson IRAB. Effect of resistance training on self-reported physical functioning in HIV infection. Med Sci Sports Exerc. 2001; 33(11):1811-1817.

16. Santos C, Silva JAF, Bittencourt G, Mota J, Navarro F. O efeito do exercício físico agudo e crônico na resposta imunológica de indivíduos portadores do HIV. RBPFEX. 2007; 1(4):01-16.

17. Soares TCM, Souza HAG, Guerra LMM, Pinto E, Milan EP, Dantas PM, et al. Morphology and biochemical markers of people living with HIV/aids undergoing a resistance exercise program: clinical series. J Sports Med Phys Fitness. $2011 ; 51(3): 462-466$.

18. Oliveira JS, Lima FL, Saldanha AAW. Qualidade de vida em pessoas com mais de 50 anos HIV+: um estudo comparativo com a população geral. DST-J Doenças Sex Transm. 2008; 1(1):179-184.

19. Enright PL, Sherrill DL. Reference equations for the six-minute walk in healthy adults. Am J Respir Crit Care Med. $1998 ; 158(1): 1384-1387$.

20. OMS. Departamento de Saúde Mental e Dependência Química. WHOQOL-HIV BREF. 2002. Disponível em: http:// www.ufrgs.br/psiquiatria/psiq/whoqol_hiv_03.pdf

21. OMS. Departamento de Saúde Mental e Dependência Química. Instrumento WHOQOL-HIV - Manual do Usuário. 2002. Disponível em: http://www.ufrgs.br/psiquiatria/psiq/whoqol_hiv_01.pdf

22. Pedroso B. software Microsoft Excel - um software de ampla acessibilidade. Disponível em: http://www.brunopedroso.com.br/whoqol-hiv.htm instrumentos W.

23. Fernandes TAB, Garcia A, Trombeta JCS, Fraga GA, Vieira-Junior RC, Prestes J, et al. Efeitos do treinamento físico combinado realizado na intensidade do limiar anaeróbio sobre a composição corporal e sistema imune de sujeitos HIV+. Rev Bras Ci e Mov. 2013;21(4):5-12.

24. Pereira FLV, Galdino SÁ. Exercício Físico e aids. Pensamento Plural: Rev Científica da UNIFAE. 2010; 4(1):32-41.

25. Oliveira FSB, Alves JSA, Paes PP. O exercício físico resistido como terapia não medicamentosa em pessoas que vivem com HIV/aids e lipodistróficas. Lecturas Educación Física y Deportes. 2013; 18(181):1-5. Disponível em:< http://www.efdeportes.com/efd181/o-exercicio-fisico-resistido-em-pessoas-com-hiv-aids.htm> Acesso em: 05 jan. 2013.

26. Palermo PCG, Feijó OG. Exercício Físico e Infecção pelo HIV: atualização e recomendações. Rev Bras Fisiologia do Exercício. 2003; 2(3):221-246. 
27. Leite GE, Gori RMA. Atividade física para portadores do vírus hiv: investigando a realidade Jataiense. Pensar a Prática. 2004; 7(1):11-27.

28. Matsudo SM, Matsudo VKR, Barros-Neto TL. Impacto do envelhecimento nas variáveis antropométricas, neuromotoras e metabólicas da aptidão física. Rev Bras Ciên Mov. 2000; 8 (4):21-32.

29. Freitas CC, Oliveira DM, Santos D. Efeito do exercício resistido frente ao metabolismo de lipídios durante e pós treinamento. Lecturas Educación Física y Deportes. 2013; 13(130):1-5. Disponível em:< http://www.efdeportes. com/efd130/metabolismo-de-lipidios-durante-e-pos-treinamento.htm> Acesso em: 05 jan. 2013.

30. Gomes A. Imagem Corporal na toxicodependênca e VIH/SIDA. Universidade Nova Lisboa. Tese (Doutorado em Psicologia Aplicada) Lisboa, 2006. $326 \mathrm{f}$.

31. Santos WR, Paes PP, Bueno SMV, Fernandes APM. Exercício físico como tratamento complementar na redistribuição da gordura corporal na síndrome da lipodistrofia em pessoas vivendo com HIV/aids. Estudo piloto. Lecturas Educación Física y Deportes. 2011; 16(160):1-5. Disponível em: < http://www.efdeportes.com/efd160/exercicio-fisico-em-pessoas-com-hiv-aids.htm.> Acesso em: 05 out. 2012.

32. Monteiro MF, Sobral-Filho DC. Exercício físico e o controle da pressão arterial. Rev. Bras. Med Esporte. 2004; 10(6):513-516.

33. Rech V, Teixeira L, Sachetti A, Fontana C, Romano S. Pressão arterial após atividades físicas orientadas em idosos hipertensos. Saúde e Pesquisa. 2013; 6(1):75-83.

34. Pinheiro WL, Gadelha CJMU. Atividade física para indivíduos infectados pelo vírus da imunodeficiência humana: uma revisão sistemática. Lecturas Educación Física y Deportes. 2008; 18(180):1-5. Disponível em:< http://www. efdeportes.com/efd180/atividade-fisica-pelo-virus-da-imunodeficiencia.htm> Acesso em: 05 out. 2012.

35. Marin L, Campos Pinto CA, Dalmoro K. Alterações cardiorrespiratórios de idosos portadores de síndrome da imunodeficiência humana adquirida. Fisisinectus. 2013; 1(1):25-34.

36. Borges A, Zirzanowsky R, Oliveira MA. Prescrição de atividades físicas para pessoas portadoras do vírus HIV/ AIDS. Lecturas Educación Física y Deportes. 2008; 18(184):1-5. Disponível em:< http://www.efdeportes.com/ efd180/atividade-fisica-pelo-virus-da-imunodeficiencia.htm> Acesso em: 05 out. 2012.

37. Rodrigues VD, Ávila WR. Relação da atividade física sistematizada com portadores de HIV / AIDS. Lecturas Educación Física y Deportes. 2008; 13(119):1-5. Disponível em:< http://www.efdeportes.com/efd119/relacao-daatividade-fisica-sistematizada-com-portadores-de-hiv-aids.htm.> Acesso em: 05 out. 2012.

38. Rombaldi AJ, Leite CF, Santos MNS. Efeitos do Exercício Físico em Marcadores Imunológicos de Pessoas com HIV/ Aids: Estudo de Revisão. Rev Bras Ciên da Saúde. 2012; 16(2):253-258.

39. Souza PML, Jacob-Filho W, Santarém JM, Silva AR, Li HY, Burattini MN. Progressive resistance training in elderly HIV-positive patients: does it work? Clinics. 2008; 63(5):619-624.

40. Abbas Ak, Lichtman AH, Pillai S. Imunologia celular e molecular. Rio de Janeiro: Elsevier; 2011. 592p.

41. Lira FS, Rosa-Neto J, Pimentel GD, Caperuto EC, Mello MT, Rodrigues B, et al. Importância dos efeitos fisiológicos do exercício na promoção da saúde. Rev Inova Saúde. 2012; 1(4):41-56.

42. Kluthcovsky ACGC, Kluthcovsky FA. O WHOQOL-bref, um instrumento para avaliar qualidade de vida: uma revisão sistemática. Rev psiquiatr Rio Gd Sul. 2009; 31(3S): 1-12.

43. Santos ECM, Franca-Junior I, Lopes F. Quality of life of people living with HIV/AIDS in São Paulo, Brazil. Rev Saúde Pública. 2007; 41(2):64-71. 